\title{
Short communication: Association between udder health status and blood serum proteins in dairy cows
}

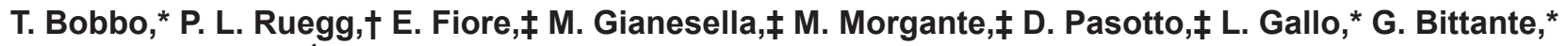 \\ and A. Cecchinato*1 \\ *Department of Agronomy, Food, Natural Resources, Animals and Environment (DAFNAE), University of Padova, Viale dell'Università 16, \\ 35020 Legnaro, Padova, Italy \\ †Department of Dairy Science, University of Wisconsin-Madison, 1675 Observatory Drive, Madison 53706 \\ łDepartment of Animal Medicine, Production and Health, University of Padova, Viale dell'Università 16, 35020 Legnaro, Padova, Italy
}

\section{ABSTRACT}

The aim of this study was to investigate the association between udder health $(\mathrm{UH})$ status and blood serum proteins (i.e., total protein, albumin, globulin, and albumin-to-globulin ratio) in dairy cows. Blood and milk samples were collected from 1,508 cows of 6 different breeds (Holstein Friesian, Brown Swiss, Jersey, Simmental, Rendena, and Alpine Grey) that were housed in 41 multibreed herds. Bacteriological analysis was performed on milk samples with somatic cell count (SCC) $>100,000$ cells $/ \mathrm{mL}$ and bacteria identification was confirmed by multiplex-PCR assays. Milk samples were grouped into 7 clusters of UH status: healthy (cows with milk SCC $<100,000$ cells/mL and not cultured); culture-negative samples with low, medium, or high SCC; and culture-positive samples with contagious, environmental, and opportunistic intramammary infections. Data of blood serum proteins were analyzed using a linear mixed model that included the fixed effects of stage of lactation, parity, breed, herd productivity (high or low production) and UH status, and the random effect of herd-date within herd productivity. Culture-negative samples with high milk SCC, which were most likely undergoing a strong inflammatory response and whose pathogens could not be isolated because they were engulfed by macrophages or because they had already cleared, and milk samples infected by contagious and environmental bacteria were associated with greater globulin concentrations (and lower albumin-to-globulin ratio) in blood. Variation in blood serum proteins seems to be associated with inflammatory status rather than infection, as serum globulin significantly increased in UH status groups with the highest milk SCC and no differences were observed

Received May 3, 2017.

Accepted August 21, 2017.

${ }^{1}$ Corresponding author: alessio.cecchinato@unipd.it among intramammary infections pathogens. Blood serum proteins can be a mammary gland inflammation indicator, but cannot be used to differentiate among different UH status groups.

Key words: subclinical mastitis, intramammary infection, blood serum proteins, dairy cattle

\section{Short Communication}

Udder health (UH) represents a critical issue for milk production, and monitoring the health status of the animals is of great importance for dairy farm economics. Bovine mastitis, an inflammatory status of the mammary gland in response to an infection, is the most prevalent production disease and strongly affects dairy herd income by decreasing milk yield and quality, cow welfare, fertility, and longevity (Seegers et al., 2003). Thus, a successful immune response of the animal to infection can improve milk production and reduce the treatment costs.

Blood serum proteins have been used as possible markers for assessing the immune status in dairy cows (Piccinini et al., 2004). In a previous study (Bobbo et al., 2017a), we characterized the variation in blood serum proteins [i.e., total protein, albumin, globulin and albumin-to-globulin ratio (A:G)] in dairy cattle housed in multibreed herds and concluded that environmental factors (e.g., herd productivity), breed, and individual cow factors (stage of lactation and parity) must be considered to appropriately interpret blood serum proteins as cow health indicators. After adjusting for those factors, a linear relationship between blood serum proteins and milk SCS was identified. Cows with high SCC in milk had greater total protein and globulin concentrations in blood serum, an expected result given that $\alpha-$ and $\gamma$-globulins are involved in the immune response of the mammary gland.

Besides the increased milk SCC related to the inflammatory status of the mammary gland, specific 
IMI pathogens can elicit differential immune responses (Bannerman et al., 2004) and differences in SCC variation (de Haas et al., 2002). To our knowledge, variation in blood serum proteins among various UH status groups has not been investigated yet. Therefore, the objective of the present study was to assess the association between UH status and blood serum proteins in dairy cows. Rather than simply focus on microbiologically positive infections, we evaluated both the IMI and the resulting inflammatory response.

This study is part of the Cowplus Project, described in detail in Bobbo et al. (2017a,b). Briefly, blood and milk samples were collected from 1,508 cows belonging to 3 specialized dairy breeds (Holstein Friesian, Brown Swiss, and Jersey) and 3 dual-purpose breeds of Alpine origin (Simmental, Rendena, and Alpine Grey), that were housed in 41 multibreed herds of Trentino region (northeast Italy). In a calendar year, 1 herd per day was visited once and only clinically healthy cows at the moment of the visit were sampled during an evening milking. Details on procedures used to collect and analyze blood samples for serum proteins determination can be found in Bobbo et al. (2017a). From each selected cow, a composite milk sample $(40 \mathrm{~mL})$ for bacteriological analyses and a second sample $(50 \mathrm{~mL})$ for SCC determination were collected. Details on milk samples collection, storage, and analyses were reported in Bobbo et al. (2017b). Cows with milk SCC $<100,000$ cells $/ \mathrm{mL}$ were considered potentially healthy and were not subjected to microbiological examination. Bacteriological analysis was performed on milk samples with SCC $>100,000$ cells $/ \mathrm{mL}$ according to the guidelines of National Mastitis Council (NMC, 1999). Briefly, each sample was plated twice by streaking $0.01 \mathrm{~mL}$ of milk onto Columbia Blood Agar containing 5\% defibrinated sheep blood (Oxoid Ltd., Basingstoke, UK), incubated aerobically at $37 \pm 1^{\circ} \mathrm{C}$, and examined after 24 and 48 h. Grown colonies were characterized mainly according to their morphology, hemolytic features, Gram staining, catalase, oxidase, coagulase reactions, and biochemical properties (NMC, 1999). Gram-positive microorganisms were differentiated as staphylococci and streptococci by the catalase reaction. The coagulase tube test in rabbit plasma (bioMérieux Italia S.p.A., Grassina, Italy), was used to differentiate coagulase positive from coagulase-negative Staphylococcus spp.

The Christie, Atkins, Munch-Petersen (CAMP) test was used for the presumptive identification of Streptococcus agalactiae. Enterococcus spp. was confirmed plating suspected colonies onto Bile Esculin Agar (Oxoid Ltd.). Lactococcus lactis and Aerococcus viridans were identified by using API system (bioMérieux Italia S.p.A.). Gram-negative bacteria were identified by their morphological features on MacConkey agar, eosin methylene blue agar, Kligler iron agar, urea agar, and SIM agar (Oxoid Ltd.). Bacterial genus confirmation and species identification of Staphylococcus, Streptococcus, and Escherichia coli strains was confirmed by multiplex-PCR assays, as previously described by Shome et al. (2011) with minor changes related to Taq DNA polymerase (KAPA2G FastMultiplex PCR Kit, Kapa Biosystems, Wilmington, MA) and cycling protocol.

Contaminated plates presented 3 or more different colony types, with no prevalence of a single colony type (NMC, 1999). Samples were classified as culture-negative when no bacteria were isolated or no significant growth $(<1,000 \mathrm{cfu} / \mathrm{mL})$ was observed within $48 \mathrm{~h}$ of incubation, with the exception of potential contagious IMI cases, for which identification was performed even when 1 colony $(\geq 100 \mathrm{cfu} / \mathrm{mL})$ was isolated.

As reported in Stocco et al. (2017), farms were classified as high or low production. Briefly, the net energy content of milk $(\mathrm{kcal} / \mathrm{kg})$ yielded the day of sampling by each cow was estimated, converted to kilojoules per kilogram and multiplied by the individual daily milk production $(\mathrm{kg} / \mathrm{d})$ to obtain the individual daily milk energy production of each cow $(\mathrm{kJ} / \mathrm{d})$. Data were then analyzed using the GLM procedure of SAS (SAS Institute Inc., Cary, NC), including herd, breed, parity, and DIM of cows, to estimate the least squares means (LSM) of the average daily milk energy production of each herd. The 41 farms were ranked according to the estimated LSM of their average daily milk energy yield, and were classified as low- $(\mathrm{n}=21)$ or high-producing $(n=20)$ based on the median value of their LSM.

Seven clusters of UH status were identified (Bobbo et al., 2017b): healthy (cows with milk SCC $<100,000$ cells / $\mathrm{mL}$ and not tested for the presence of bacteria); culturenegative samples with low (No Growth_L), medium (No Growth_M), and high (No Growth_H) SCC (divided on the basis of the SCS 25th and 75th percentiles); and culture-positive samples with contagious, environmental, and opportunistic IMI.

Data of blood serum proteins were analyzed using the MIXED procedure of SAS with the linear mixed model applied also in Bobbo et al. (2017b):

$$
\begin{aligned}
y_{i j k l m n o}= & \mu+\text { DIM }_{i}+\text { Parity }_{j}+\text { Breed }_{k}+\text { UH status } \\
& +H P_{m}+\operatorname{HTD}_{n}(H P)_{m}+e_{i j k l m n o}
\end{aligned}
$$

where $y_{i j k l m n o}$ is the investigated trait (blood serum proteins); $\mu$ is the overall mean; $D I M_{i}$ is the fixed effect of the $i$ th class of DIM ( $i=6$ classes of 60 -d intervals); Parity $_{j}$ is the fixed effect of the $j$ th parity $(j=1$ to $\geq 4)$; Breed $_{k}$ is the fixed effect of the $k$ th breed ( $k=$ Holstein 
Table 1. Results of the bacteriological analysis of 639 composite milk samples with SCC $>100,000$ cells $/ \mathrm{mL}^{1}$

\begin{tabular}{|c|c|c|}
\hline Udder health status group & No. & $\%$ \\
\hline Contagious & 172 & 26.9 \\
\hline Staphylococcus aureus & 151 & 23.6 \\
\hline Streptococcus agalactiae & 11 & 1.7 \\
\hline Staphylococcus aureus + Streptococcus dysgalactiae & 5 & 0.8 \\
\hline Staphylococcus aureus + Streptococcus agalactiae & 2 & 0.3 \\
\hline Staphylococcus aureus + Enterococcus spp. & 1 & 0.2 \\
\hline Staphylococcus aureus + Streptococcus uberis & 1 & 0.2 \\
\hline Staphylococcus aureus + other streptococci & 1 & 0.2 \\
\hline Environmental & 102 & 16.0 \\
\hline Other streptococci & 26 & 4.1 \\
\hline Enterococcus spp. & 21 & 3.3 \\
\hline Streptococcus dysgalactiae & 16 & 2.5 \\
\hline Streptococcus uberis & 14 & 2.2 \\
\hline Proteus spp. & 9 & 1.4 \\
\hline Aerococcus viridans & 5 & 0.8 \\
\hline Escherichia coli & 5 & 0.8 \\
\hline Klebsiella spp. & 2 & 0.3 \\
\hline Bacillus spp. & 1 & 0.2 \\
\hline Enterobacter spp. & 1 & 0.2 \\
\hline Lactococcus lactis & 1 & 0.2 \\
\hline Aerococcus viridans $+\mathrm{CNS}$ & 1 & 0.2 \\
\hline Opportunistic & 59 & 9.2 \\
\hline CNS & 59 & 9.2 \\
\hline No growth & 245 & 38.3 \\
\hline Contaminated & 61 & 9.5 \\
\hline
\end{tabular}

${ }^{1}$ Adapted from Bobbo et al. (2017b).

Friesian, Brown Swiss, Jersey, Simmental, Rendena, and Alpine Grey); UH status is $_{\text {in }}$ the fixed effect of the $l$ th group of infection status $(l=$ healthy, No Growth_L, No Growth_M, No Growth_H, contagious, environmental, opportunistic); $H P_{m}$ is the fixed effect of the $m$ th herd productivity [ $m=$ high or low production]; $\operatorname{HTD}_{n}(H P)_{m}$ is the random effect of the $n$th herd-date ( $\mathrm{n}=41$ levels) within the $m$ th herd productivity; and $e_{i j k l m n o}$ is the random residual. A normal distribution was assumed for herd-date and residuals, with a mean of zero and a variance of $\sigma_{h}^{2}$ and $\sigma_{e}^{2}$, respectively. Proportion of variance explained by herd-date was determined by dividing the corresponding variance component by the total variance. Pairwise comparisons between UH status groups were performed using the Tukey correction $(P<0.05)$.

Results of the bacteriological analysis were reported in Table 1. Healthy animals represented about $58 \%$ of the samples and had a mean milk SCS of 1.48. Due to the low frequency of recovery of some pathogens, we classified them as contagious, environmental, and opportunistic, a classification commonly used based on reservoir and mode of transmission. Contagious IMI (mean milk SCS $=4.81$ ), identified if at least 1 colony $(\geq 100 \mathrm{cfu} / \mathrm{mL})$ of Staphylococcus aureus or Strep. agalactiae was isolated, were the most frequent, corresponding to about $27 \%$ of the cultured samples.
Environmental and opportunistic pathogens were considered to cause an IMI if at least 10 grown colonies/ type $(1,000 \mathrm{cfu} / \mathrm{mL})$ were isolated in the plate. Environmental IMI $(16 \%$, mean milk SCS $=4.70)$ were caused by Enterococcus spp., Streptococcus dysgalactiae, Streptococcus uberis, Proteus spp., A. viridans, E. coli, Klebsiella spp., Bacillus spp., Enterobacter spp., L. lactis, and other streptococci. Opportunistic IMI (9\%, mean milk SCS $=4.60$ ) were related to the presence of CNS in milk. Sixty-one samples were contaminated and thus excluded from the analysis, whereas 245 were culture-negative (no growth), even if the mean milk SCS was relatively high (4.38). Three hypotheses were considered to explain the high SCC in samples with no bacterial growth, namely (1) healing process and spontaneous elimination of the infection at the moment of the sampling, (2) high level of inflammation and internalization of the pathogens by phagocytes, and (3) presence of false-negative results due to a dilution effect of composite samples. Culture-negative samples were thus divided into 3 subgroups on the basis of SCS 25th and 75th percentiles as culture-negative samples with low SCS (No Growth_L; 61 samples with mean SCS = 3.21), medium SCS (No Growth_M; 122 samples with mean SCS $=4.07$ ), and high SCS (No Growth_H; 62 samples with mean $\mathrm{SCS}=6.13$ ).

Coefficient of variation of blood serum proteins ranged from 7 to $16 \%$ (Table 2). Serum total protein averaged $74.17 \mathrm{~g} / \mathrm{L}$, resulting from the sum of albumin and globulin (30.77 and $43.40 \mathrm{~g} / \mathrm{L}$, respectively). Albumin-to-globulin ratio had a mean value of 0.72 .

In accordance to our previous results (Bobbo et al., 2017a), the proportion of variance explained by herddate was approximately $20 \%$ and all explanatory variables were important sources of variation of the blood serum proteins, with the exception of herd productivity, which was only associated with albumin concentration in blood (Table 3). In particular, the association previously observed between blood serum proteins and mammary gland inflammation, determined by the measure of SCC in milk, is now supported by the evidence of an association also with UH status (Table 3 ).

Table 2. Descriptive statistics of serum proteins $(\mathrm{n}=1,447)^{1}$

\begin{tabular}{lrrrr}
\hline Serum protein & Mean & CV, \% & P1 & \multicolumn{1}{c}{ P99 } \\
\hline Total protein, g/L & 74.17 & 7.5 & 61.29 & 88.66 \\
Albumin, g/L & 30.77 & 6.9 & 24.84 & 35.22 \\
Globulin, g/L & 43.40 & 13.5 & 32.83 & 61.03 \\
Albumin:globulin & 0.72 & 15.9 & 0.43 & 0.99 \\
\hline
\end{tabular}

${ }^{1} \mathrm{P} 1=1$ st percentile; $\mathrm{P} 99=99$ th percentile. 
Table 3. Results of ANOVA ( $F$-value and $P$-value) for serum proteins

\begin{tabular}{|c|c|c|c|c|c|c|c|c|}
\hline Effect & \multicolumn{2}{|c|}{ Total protein, g/L } & \multicolumn{2}{|c|}{ Albumin, g/L } & \multicolumn{2}{|c|}{ Globulin, g/L } & \multicolumn{2}{|c|}{ Albumin:globulin } \\
\hline $\begin{array}{l}\text { Herd productivity } \\
\text { HTD }, \% \%\end{array}$ & 2.4 & 0.133 & 14.8 & $<0.001$ & 0.0 & 0.945 & 21.4 & 0.187 \\
\hline Breed & 7.2 & $<0.001$ & 7.1 & $<0.001$ & 8.9 & $<0.001$ & 12.4 & $<0.001$ \\
\hline DIM & 3.2 & 0.007 & 7.6 & $<0.001$ & 3.3 & 0.006 & 4.7 & $<0.001$ \\
\hline Parity & 28.7 & $<0.001$ & 2.8 & 0.040 & 23.2 & $<0.001$ & 15.6 & $<0.001$ \\
\hline
\end{tabular}

${ }^{1}$ HTD $=$ herd-date effect expressed as proportion of variance explained by herd-test date calculated by dividing the corresponding variance component by the total variance.

${ }^{2} \mathrm{UH}$ status $=$ udder health status groups, defined according to Bobbo et al. (2017b): healthy (cows with milk SCC $<100,000$ cells $/ \mathrm{mL}$ and not tested for the presence of bacteria), culture-negative samples divided into 3 classes on the basis of SCS 25th and 75th percentiles: with low (No Growth_L; 100-137 cells $\times 10^{3} / \mathrm{mL}$ ), medium (No Growth_M; $137-425$ cells $\times 10^{3} / \mathrm{mL}$ ), and high (No Growth_H; $>425$ cells $\times 10^{3} / \mathrm{mL}$ ) SCC, culture-positive samples with contagious, environmental, and opportunistic IMI.

${ }^{3} \mathrm{RMSE}=$ root mean squared error.

Greater total protein concentrations were measured in blood of cows infected by contagious pathogens and in animals whose milk was characterized by medium to high SCC, but no bacteria were isolated (No Growth_M and No Growth_H) in comparison to healthy cows (Figure 1a). As serum albumin concentration did not differ among UH status groups (Figure 1b), with the exception of a slightly decrease during environmental IMI in comparison to healthy animals, the increase in total protein can be explained by an increase in the globulin fraction. Culture-negative samples with high milk SCC (NoGrowth_H), which were most likely undergoing a strong inflammatory response and pathogens could possibly not be isolated because they were engulfed by macrophages (Bobbo et al., 2017b), and milk samples infected by contagious and environmental bacteria were associated with greater globulin concentration in blood (Figure 1c). As a consequence, lower A:G was reported for those $3 \mathrm{UH}$ clusters (Figure 1d). Variation in serum proteins was not observed with opportunistic IMI. Because CNS are commonly found on udder skin, some of the culture-positive results may be due to teat skin contamination during the collection of composite samples, rather than a real mammary gland infection (Thorberg et al., 2009). Thus, as the increase in globulin concentration was observed in $\mathrm{UH}$ status groups with the highest milk SCS $(6.13,4.80$, and 4.70, for No Growth_H, contagious, and environmental IMI, respectively) and no differences were observed among IMI pathogens, variation in serum proteins seems to be associated with inflammation rather than infection. These findings support the results previously reported in Bobbo et al. (2017b), in which the greatest impairment in milk composition and technological properties related to cheese production was observed in the
$2 \mathrm{UH}$ status groups with the highest milk SCC (i.e., contagious IMI and culture-negative samples with high SCC).

Somatic cells and blood serum proteins seem to be 2 key components of the immune response. Once inside the teat cistern, the contact between pathogens and leukocytes and epithelial cells induces the activation of the innate immune system. After pathogen recognition, realized through the expression of specific receptors such as the cytokines toll-like receptors and CD14, bacterial growth is inhibited through the recruitment of circulating neutrophils from the bloodstream to the mammary tissue (Wellnitz and Bruckmaier, 2012). Leukocytes release several cytokines, including tumor necrosis factor- $\alpha$ and IL-8, which induce the synthesis of positive acute phase proteins, such as the $\alpha$-globulins serum amyloid A and haptoglobin (Viguier et al., 2009). Alpha-globulins are produced in the liver and migrate to the site of infection to inhibit growth of microbes; thus, higher levels can be detected in the blood during inflammatory status, partially explaining the increase in globulin concentration observed in the serum of cows with high SCC in milk (Figure 1c). Serum amyloid A and haptoglobin have already been recognized as possible mastitis indicators, in association with the traditional SCC (Petersen et al., 2004).

The $\gamma$-globulin fraction is actively involved in the defense system. In fact, different immunoglobulin isotypes prevent colonization by bacteria ( $\operatorname{IgA}$ ) and support phagocytosis by neutrophils (IgG and IgM; Korhonen et al., 2000). In particular, animals with a successful immune response to IMI pathogens should have rapid and effective neutrophils recruitment ability and high levels in blood serum of the opsonizing antibodies IgG2, with subsequent leakage into milk (Burton and Ers- 

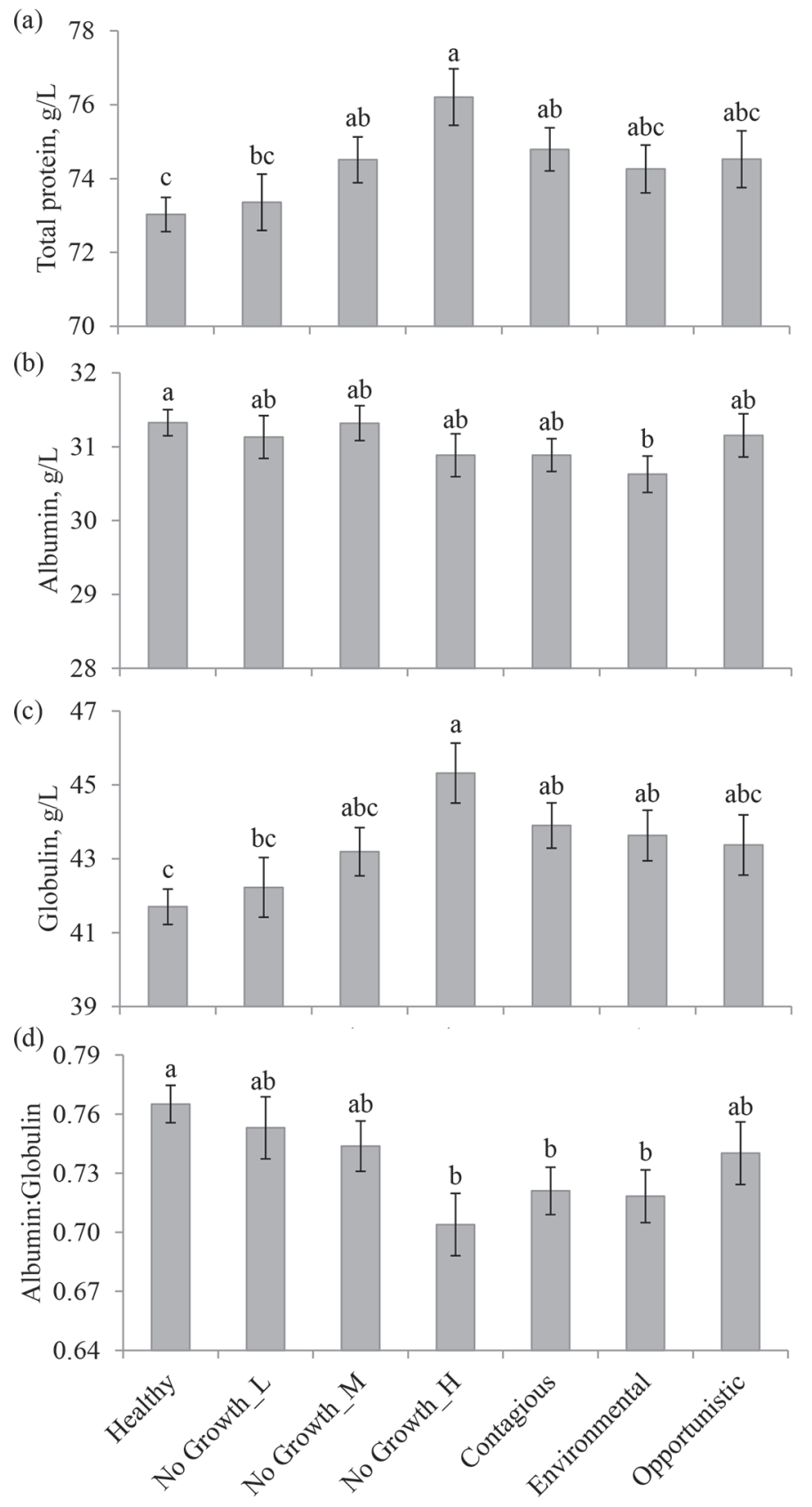

Figure 1. Least squares means and SE of serum proteins by different udder health status groups. Groups were defined according to Bobbo et al. (2017b): healthy (cows with milk SCC $<100,000$ cells $/ \mathrm{mL}$ and not tested for the presence of bacteria); culture-negative samples were divided into 3 classes on the basis of SCS 25th and 75th percentiles with low (No Growth_L; 100-137 cells $\times 10^{3} / \mathrm{mL}$ ), medium (No Growth_M; 137-425 cells $\times 10^{3} / \mathrm{mL}$ ) and high (No Growth_H; $>425$ cells $\times 10^{3} / \mathrm{mL}$ ) SCC, culture-positive samples with contagious, environmental, and opportunistic IMI. The LSM with different letters $(\mathrm{a}-\mathrm{c})$ statistically differ (Tukey adjusted $P<0.05$ ).

kine, 2003). Thus, when appropriate antibodies bind bacteria, pathogen recognition and destruction by neutrophils is facilitated. A positive correlation between
IgG2 level in serum and clinical mastitis has been observed in Holstein Friesian cows (Mallard et al., 1983). Conversely, a genetic deficiency in IgG2 synthesis was associated in Danish Red cattle with a higher frequency of disease caused by pyogenic bacteria, including mastitis (Nansen, 1972). To synthesize pathogen-reactive IgG2 antibodies, B lymphocytes need IFN- $\gamma$ and other cytokines, secreted by $\mathrm{T}$ cells only after recognition of specific antigens during infection (Burton and Erskine, 2003). Thus, the increased synthesis of $\gamma$-globulins during mammary gland inflammation may further explain the greater globulin concentration in serum of cows with high milk SCC.

Results of this study suggest that blood serum proteins (i.e., total protein, albumin, globulin, and A:G) can be a mammary gland inflammation indicator, but cannot be used to differentiate among different UH status groups. However, as different etiological agents can induce differential immune responses and stimulate the synthesis of different proinflammatory cytokines (Oviedo-Boyso et al., 2007), further studies will be required to deeply investigate variation in specific globulin fractions among different clusters of UH status.

\section{ACKNOWLEDGMENTS}

The authors thank the Autonomous Province of Trento (Italy) for funding.

\section{REFERENCES}

Bannerman, D. D., M. J. Paape, J. W. Lee, X. Zhao, J. C. Hope, and P. Rainard. 2004. Escherichia coli and Staphylococcus aureus elicit differential innate immune responses following intramammary infection. Clin. Diagn. Lab. Immunol. 11:463-472.

Bobbo, T., E. Fiore, M. Gianesella, M. Morgante, L. Gallo, P. L. Ruegg, G. Bittante, and A. Cecchinato. 2017a. Variation in blood serum proteins and association with somatic cell count in dairy cattle housed in multi-breed herds. Animal 31:1-11. https://doi .org/10.1017/S1751731117001227.

Bobbo, T., P. L. Ruegg, E. Fiore, M. Gianesella, M. Morgante, D. Pasotto, G. Bittante, and A. Cecchinato. 2017b. Association between pathogen-specific cases of subclinical mastitis and milk yield, quality, protein composition and cheese-making traits in dairy cows. J. Dairy Sci. 100:4868-4883.

Burton, J. L., and R. J. Erskine. 2003. Immunity and mastitis. Some new ideas for an old disease. Vet. Clin. North Am. Food Anim. Pract. 19:1-45.

de Haas, Y., H. W. Barkema, and R. F. Veerkamp. 2002. The effect of pathogen-specific clinical mastitis on the lactation curve for somatic cell count. J. Dairy Sci. 85:1314-1323.

Korhonen, H., P. Marnila, and H. S. Gill. 2000. Milk immunoglobulins and complement factors. Br. J. Nutr. 84:S75-S80.

Mallard, B. A., E. B. Burnside, J. H. Burton, and B. N. Wilkie. 1983. Variation in serum immunoglobulins in Canadian Holstein-Friesians. J. Dairy Sci. 66:862-866.

Nansen, P. 1972. Selective immunoglobulin deficiency in cattle and susceptibility to infection. Acta Pathol. Microbiol. Scand. B Microbiol. Immunol. 80:49-54. 
National Mastitis Council (NMC). 1999. Laboratory Handbook on Bovine Mastitis. rev. 674 ed. Natl. Mastitis Council Inc., Madison, WI.

Oviedo-Boyso, J., J. J. Valdez-Alarcon, M. Cajero-Juarez, A. OchoaZarzosa, J. E. Lopez-Meza, A. Bravo-Patino, and V. M. Baizabal-Aguirre. 2007. Innate immune response of bovine mammary gland to pathogenic bacteria responsible for mastitis. J. Infect. 54:399-409.

Petersen, H. H., J. P. Nielsen, and P. M. H. Heegaard. 2004. Application of acute phase protein measurements in veterinary clinical chemistry. Vet. Res. 35:163-187.

Piccinini, R., E. Binda, M. Belotti, G. Casirani, and A. Zecconi. 2004. The evaluation of non-specific immune status of heifers in field conditions during the periparturient period. Vet. Res. 35:539-550.

Seegers, H., C. Fourichon, and F. Beaudeau. 2003. Production effects related to mastitis and mastitis economics in dairy cattle herds. Vet. Res. 34:475-491.
Shome, B. R., S. Das Mitra, M. Bhuvana, N. Krithiga, D. Velu, R Shome, S. Isloor, S. B. Barbuddhe, and H. Rahman. 2011. Multiplex PCR assay for species identification of bovine mastitis pathogens. J. Appl. Microbiol. 111:1349-1356.

Stocco, G., C. Cipolat-Gotet, T. Bobbo, A. Cecchinato, and G. Bittante. 2017. Breed of cow and herd productivity affect milk composition and modeling of coagulation, curd firming and syneresis. J. Dairy Sci. 100:129-145.

Thorberg, B. M., M. L. Danielsson-Tham, U. Emanuelson, and K. P. Waller. 2009. Bovine subclinical mastitis caused by different types of coagulase-negative staphylococci. J. Dairy Sci. 92:4962-4970.

Viguier, C., S. Arora, N. Gilmartin, K. Welbeck, and R. O'Kennedy. 2009. Mastitis detection: Current trends and future perspectives. Trends Biotechnol. 27:486-493.

Wellnitz, O., and R. M. Bruckmaier. 2012. The innate immune response of the bovine mammary gland to bacterial infection. Vet. J. 192:148-152. 